Vol. 7, No. 2, 2020

https://doi.org/10.23939/eem2020.02.046

UDC 336+001.8

JEL Classification Code: B26; B41; G10; G20; G30; I23

I. Alieksieiev

Lviv Polytechnic National University, Ukraine, ScD, Professor

E-mail: Ihor.V.Alieksieiev@lpnu.ua

ORCID ID: 0000-0001-6618-3100

\author{
A. Mazur \\ Lviv Polytechnic National University, Ukraine, PhD, Associate Professor \\ E-mail: Andriana.V.Mazur@lpnu.ua \\ ORCID ID: 0000-0002-5985-5674
}

A. Moroz

Lviv Polytechnic National University, Ukraine, PhD, Associate Professor

E-mail: Anatoliy.S.Moroz@lpnu.ua

ORCID ID: 0000-0001-7202-5504

\title{
METHODOLOGY OF PROSPECTIVE AND CURRENT RESEARCH IN FINANCE
}

\begin{abstract}
The article deals with issues related to research methodology in the financial field. An important aspect of the author's approach is a new look at the research, which is proposed to be considered as prospective and current. The argument for this approach is the need to combine traditional basic and applied research into a group of prospective, ie those that result in some long-term goals and can usually result in scientific novelty. Instead, current research is no less practical. It is through current research that the necessary measures are being implemented. This applies to technical, technological, organisational, economic and financial measures, which ultimately provide some improvement in the activities of any entity. The characteristics of prospective and current research are given, which determine the differences between them. In particular, such characteristics are: the expected result, the tools for the study and the composition of researchers - performers of prospective or current research. Based on the division of research into prospective and current, the different directions of these types of scientific and practical research are determined. It is noted that the formulation of tasks of different purpose and nature requires the definition of certain predefined sets of research methods. Narrowing of methodical tools can lead to erroneous results. Instead,
\end{abstract}

an integrated approach, formulated not only for a hypothetical goal and potential outcome, but also for the choice of research methods, is an important safeguard against erroneous conclusions. To do this, a matrix has been developed, in which complexes of research methods (for several examples) have been formed, which will allow to obtain the most substantiated result of the research, both prospective and current. Such examples are: economic and social efficiency of financial research, public policy in the field of finance, funding schemes for research. A study of well-known empirical and theoretical research methods has been carried out, from the standpoint of the peculiarities of financial research in scientific and practical activities. In particular, examples from the financial sphere of possible searches, with the help of general methods of analysis, synthesis, induction, deduction and analogy, are investigated and given. From empirical methods examples of directions of possible researches, with use of comparison, experiment, modeling, are considered and resulted. The generally accepted and special characteristics of research in the field of finance are considered. Among them are important for financiers the concept of science and the need to master the scientific approach to financial research; the nature and characteristics of the research process; scientific 
(theoretical) base and financial aspects of research; research priorities; directions of research of natural and social sciences; stages of scientific research; methodological approach to the study of efficiency in finance. These issues are important for researchers, as well as for students and graduate students studying in financial educationalprofessional and educational-scientific programs.

Key words: research methodology in finance, prospective and current research, general scientific methods of research in finance, empirical methods of research in finance, a complex of research methods in financial policy, effectiveness research methodology in finance.

\section{Introduction}

It is well known that methodology is always in the field of view of scientists. Based on the methodology, the most important aspects of the development of nature and society are studied. This area of human activity is at the epicenter of the relationship between people, corporations, and countries. Many scientific works have been published on improving the methodological tools to ensure the best way of functioning of human teams, optimising the activities of enterprises, organisations and institutions. In particular, scientists are improving methodological approaches to the study of the financial system. Instead, researchers often focus on those methodological aspects that relate to their subject of study.

In modern conditions, the science of methodology came from a purely philosophical study and moved to special studies of all branches of science. In some sciences, such as medicine, the methodological aspects are given special attention. In research on economic, managerial and financial issues, the issue of methodology is covered mainly in the context of a specific, rather narrow topic. These questions are limited to the consideration and justification of the subject, topic of research, as well as a description of the methods chosen for the study. If the reasons for choosing the subject of research, which determines the problem range of publications on the topic of the dissertation, are considered with sufficient arguments, then the research methods are simply chosen. In other words, well-known research methods are usually taken into account. Researchers do not delve into the methodological content and nature. That is, most often the features of the choice and justification of the choice and use of methods selected for the study remain undisclosed. This can sometimes lead to the use of an insufficiently complete set of methods and defects in the results of the study. A more complete and reasoned choice of research methods should be based either on previously developed by scientists recommendations, or on independent methodological research. When the first requires the availability of relevant results of methodological research, the second is quite time consuming, which would take a significant amount of time and would interfere with the main study. It is these considerations that motivate us to explore methodological features in the field of finance, to try to determine a set of methods for some problematic areas of financial research. In this way, it is possible to develop, firstly, a scheme of methodological approach to determine the group of necessary methods for a particular financial problem. Secondly, the substantiation of this scheme provides an opportunity to get an idea of the necessary and possibly mandatory set of issues, the solution of which will allow in any other case to determine the necessary set of research methods. Thirdly, certain sets of methods for conducting research can be used by other researchers as a ready-made and well-argued set that will allow you to conduct your own research of financial problems without wasting time on methodological reasoning.

\section{Literature review}

Many scientific works of domestic and foreign researchers, which are reflected in both scientific and educational literature, are devoted to the issues of methodology. In particular, we can cite the following examples of monographic works of general methodological nature [Garafonova, 2014; Howell, 2012; Kothari, 2004; Williams, 2016; Mints, 2017; Pernecky, 2016; Tuck \& McKenzie, 2014]. The most numerous group of publications on methodology issues are textbooks designed for students and graduate students. A number of works can be attributed to educational publications in which the problems of methodology are considered in the general philosophical sense [Cekhmistrova, 2003; Danylian \& Dzioban, 2017; Jonker \& Pennink, 2010; Konverskyi, 2010; Kraus, 2012]. The development of scientific research in all fields of knowledge requires the use of a significant number of approaches, principles, methods. In each field of knowledge, scientists and practitioners 


\section{Alieksieiev, A. Mazur, A. Moroz}

strive to explore and understand certain patterns, to identify the most essential characteristics of those processes that can later be used in practice.

It should be noted that the study of the content of the methodology has long philosophical roots, and therefore thanks to philosophers, this area of science has received serious generalised formulations of the categorical apparatus. Currently, scientists in other sciences use the achievements of philosophers and enrich the realm of methodology with new research, mostly of an applied nature. This also applies to the sciences of economics, management and finance [Kyrylenko, 2012; Martsyn, Mitsenko \& Danylenko, 2002; Mishchenko, Chornii \& Fishchuk, 2017; Orlov, Novytska \& Yatskevych, 2011; Romanchikov, 2007; Vajinskii \& Shcherbak, 2016; Zatserkovnyi, Tishaiev \& Demydov, 2017]. An important aspect of methodological research is information support, which, in particular, is devoted to the work [Martynov \& Orlov, 2013; Sharavara, 2017]. It is now generally accepted to include in $\mathrm{ScD}$ dissertations a section devoted to the methodology of research of a specific problem of such research. Examples of such works are [Azarenkova, 2007; Kharlamova, 2016; Korneiev, 2015, 2004].

The results of methodological research on the problems of the financial system, covering financial policy, areas of the financial system, etc., are published and supplement the general idea of the methodological aspects of the activities of financiers, scientists and practitioners. Among such publications in periodicals are works [Ryan, Scapens \& Theobold, 2002; Boronos, 2011; Dyba \& Maijorova, 2013; Ivanov \& Udovenko, 2015]. Of course, it should be recognized that the range of such works is wider, including research conducted and the results published in previous decades.

Examining the issues of methodological research in the field of finance and differentiating such publications by financial problems, we can see that they are quite diverse. The methodology of formation and architecture of transparent financial reporting is investigated in the dissertation [Kharlamova, 2016]. The work of Boronos V. [Boronos, 2011] is devoted to the financial potential of the territory. Theoretical and methodological principles of research of investment process in finance are covered by [Dyba \& Mayjorova, 2013]. In the article [Ivanov, 2015] there are proposed the results of developing a methodological approach to assessing the effectiveness of measures in the field of deregulation. The methodology of classification of financial flows of insurance companies is considered in the work [Kneisler, 2015]. Methodological approaches to the flexibility of the financial system are described in the monograph by Laktionova O. [Laktionova, 2016]. Theoretical and methodological issues of balancing the finances of enterprises are set out in the publication [Lomachynska, 2009]. Issues of financial security of the enterprise are considered in many works, in particular Martiusheva L. studied this issue from a methodological standpoint [Martiusheva, 2011]. Paientko T. investigated the problem of institutionalisation of fiscal regulation of financial flows [Paientko, 2013]. Methodological aspects of public finance research are studied in the article by Tulai O. [Tulai, 2019]. The work [Volokhova, 2014] reveals the methodology of the study of financial decentralisation by type.

Many studies of financial problems with an emphasis on the methodological principles of scientific research are in the foreign literature. An example of publications of such studies on specific topics in particular is the article, which examines research methods and methodology in finance and accounting [Ryan, Scapens \& Theobold, 2002]. In articles [Schmidt, 1982] Reinhard H. Schmidt analyses the relationship between methodology and financial economics; suggests considering capital market theory as a successful research program; the author prefers a behavioral approach to business financing as opposed to an economic approach. In his publication, Sean Peek considers small business financing options that bypass traditional banks. Williams C [Williams, 2007], based on a comparison of management research strategies in the two periods, 1995-97 and 1985-87, draws conclusions about trends in research strategy reports, as well as about the rationale for research design.

The study of many aspects of the functioning of the financial system (as we see from the examples of scientific papers, as well as what is well known from dissertation research) is quite deep in the sense of considering purely financial problems. Instead, in terms of deepening the methodological aspects, from the subject of the dissertation to the analysis of the possibilities of applying research methods for their wider use, it is 
necessary to note the local nature in this sense. That is, methodological issues are disclosed only for a specific study, for the selected subject area and no attempt is made to expand the range of methodological tools for other financial and economic problems, ie the methodological apparatus itself is not improved.

The purpose of the article is to improve approaches to the study of methodology in the field of finance, to clarify the nature and features of the use of certain well-known research methods on financial instruments, financial relations, financial system, financial efficiency, financial policy, and to identify areas for research methods for study of financial problems.

\section{Methodological approach}

When it comes to a methodological approach to the methodology itself, there is a phenomenon of the second order of research. That is, there is a problem of research methods for the research methods themselves. Obviously, to study research methods it is necessary to use well-known approaches to well-known methods. Therefore, we have chosen to study the methodology of financial research methods of analysis and synthesis, historical method, matrix method and method of description to compare and contrast such complex issues as, in particular, the formation of complex methods of financial policy research, economic and social efficiency of financial measures, financial research, etc.

Thus, analysing and covering a wide range of methodological categories, we have chosen a context in which the issues will be gradually considered: firstly, the classification of types of research depending on their purpose and time requirements and coverage of different types of resources; secondly, substantiation of the topic and composition of methods for the implementation of research in the field of finance; thirdly, the characteristics of well-known research methods for use in the field of finance; fourthly, a description of the generally accepted and special characteristics of the research process in the field of finance.

\section{Conducting results of research. \\ Prospecctive (fundamental and applied) and current research in finance}

When it comes to research, science is mentioned first. It is from scientific activity that research processes, knowledge about research methods and directions, about desirable and probable scientific results originate. Thus, if we keep in mind the training of personnel of different levels of qualification, there is always a ranking and separation of a certain range and amount of information that should be submitted for the training of bachelors, masters, PhDs. It is well known that this sequence of professional growth expands the range of research methods and, accordingly, increases the amount of educational material. Instead, for each of these educational levels, knowledge of some ascending positions is required, in particular the division of research into certain groups.

Scientific or research activity is an activity aimed at obtaining and applying new knowledge, including: basic and applied research.

Basic research can be conducted as experimental or theoretical. They are aimed at gaining new knowledge about the basic laws of construction, functioning and development of man, society, environment; the result of basic research is the discovery of phenomena, natural effects, and so on. In the financial and economic sphere, basic research is conducted mainly in a theoretical way and aims to identify trends in economic development.

Applied research is aimed primarily at applying new knowledge to achieve practical goals and solve specific problems; the result of applied scientific research in material production are new technological processes, machines, mechanisms, devices, etc .; in intangible production such results are certain methodological developments, descriptions of recommendations, procedures for performing certain actions, etc. In the field of economics and finance, applied research should determine the prospects and effectiveness of new economic mechanisms, financial instruments and others.

Research in any field of human activity may have a different purpose and, accordingly, a different tool base, and hence differences in the composition of research performers. When it comes to research, which is undoubtedly promising, aimed at using a wide range of the latest research tools and resources, aimed at developing new designs and technologies for production, making certain recommendations for future management, they can be called perspective. In the scientific sense, such studies aim to obtain a result in the form of a certain scientific novelty. 


\section{Alieksieiev, A. Mazur, A. Moroz}

If it is necessary to obtain some improvement in the activities of a particular institution, to achieve some positive (according to the selected criteria) result in the work, then it may be a study to achieve certain changes in production and / or management. Thus production activity is activity of both industrial enterprises of any kind of economic activity, and activity of scientific, educational, financial and credit establishments. Such studies are quite acceptable to call current.

Thus, the difference between perspective (scientific) and current research is, firstly, in the expected result, secondly, in the composition of the tools used to obtain this result (although in both cases the same tools can be used), thirdly, as a part of executors-researchers.

Thus, as noted above, perspective (scientific) research is aimed at obtaining scientific novelty, which differs significantly from the knowledge that was known before the research. The current study is intended to obtain information about the possibility of changes in the parameters of the enterprise, organisation, and institution. In other words, the current study involves changes in known indicators using well-known methods.

As for the tools used in perspective (scientific) and current research, they may be the same, especially for research of humanitarian and financial and economic nature. Only fundamental (in the fields of physics, chemistry, biology) and applied (technical) research may require special tools, ie such tools, which itself can be innovative, carries elements of scientific novelty. As for financial research, they use mainly publicly available and special financial statements, which are processed using computers and software products. A novelty, as a rule, in scientific financial research is a set of ideas of researchers and the results obtained.

The performers are important for any research. Thus scientific research is carried out, as a rule, by scientific workers at possible involvement of technical workers for performance of purely technical operations. For ongoing research, it is not necessary to involve scientists to perform it. Most likely, experienced practitioners with extensive experience in a particular field and young professionals with an extraordinary view of trivial things should work here. That is, the combination of experience and certain new ideas should bring results in the process of conducting current research, which aims to improve the work, in our case, the financial structure (department, administration, ministry, etc.), or procedures for financial transactions.

Based on the above, the first practical conclusions should be made, in particular for the educational sphere, on the chosen methodological approach of our study. First, mastering the methodology of current research is important for a Master's degree. As for mastering the methodology of scientific (perspective) research, it should be done on a Doctoral degree. Secondly, an important aspect of assigning the results of our research to educational and scientific fields is a clear distinction between current and future (scientific) research, as masters must understand the objectives of financial research to improve results and not consider their future financial activities as routine financial transactions (this type of work should rather be entrusted to bachelors). As for research, masters need to gain some knowledge to understand what they should do and what scientists should do. This approach is fair, because it is common knowledge from cybernetic approaches that a system or individual performer must have knowledge and knowledge much broader and deeper than required by the work assigned to them.

\section{Substantiation of subject and methods of research in finance}

Subject of perspective (scientific) research is defined differently for fundamental and applied research.

The topic of the current study is determined in accordance with the tasks set by the management of the enterprise, organisation or institution to ensure economic development, gain competitive advantage in the market, improve the socioeconomic status of the united territorial community (UTC), region, country. Executors of current research can, if necessary, rely on the results of scientific research, the content of which opens up certain prospects in production activities.

We have already noted that the topic determines the choice of a set of methods to be used for research. In particular, for the current financial research, we propose a matrix in which, in accordance with the desired (defined) results, we propose the choice of a certain set of methods (Tab. 1). 
$\frac{0}{0}$

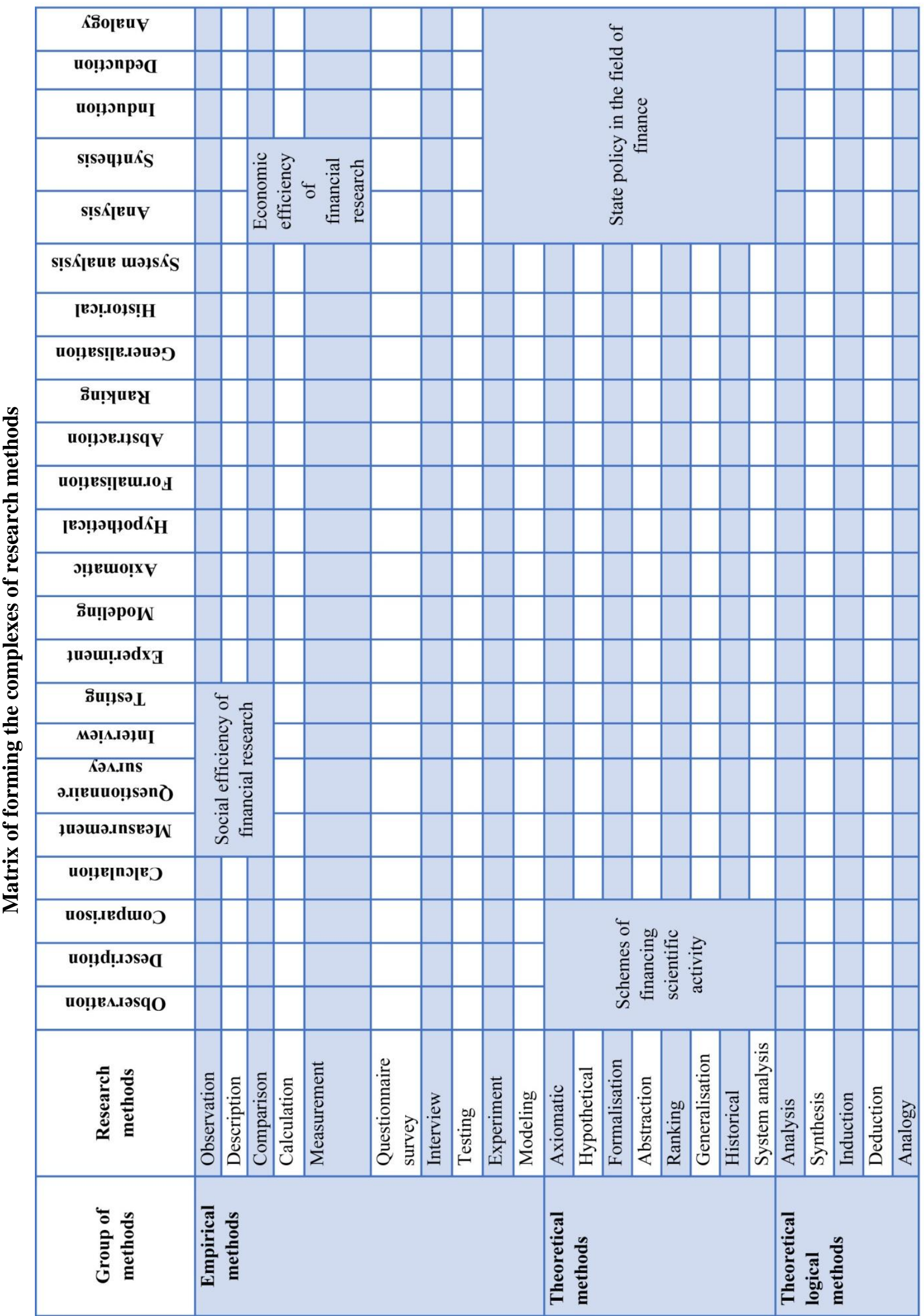




\section{Alieksieiev, A. Mazur, A. Moroz}

In determining the composition of a set of methods for the study of a particular subject area, we were guided by the conclusions of the analysis of those problematic issues that should be considered and studied in order to achieve a certain result. Of course, in each case the range of methods mentioned by us in the matrix can be supplemented. Instead, the main set of methods is determined by the need to conduct certain research operations.

Thus, the study of economic efficiency of financial problems obviously requires the use of methods of measurement, calculation, analysis and synthesis of indicators involved for comparison. In another way, it is even difficult to imagine the study of quantitative indicators of financial performance. Here it is important to note that it is a question of cost indicators, ie direct calculation of efficiency indicators, can go only after definition of indicators of technical effect. Under the technical effect, as is well known, we understand the change in the parameters of structures, technological processes, organisation of work and so on. These changes, ie the technical effect, are measured in absolute physical units, or in units of time. Therefore, it is necessary firstly to measure and calculate the technical effect, analyse its components, and then make (if necessary) certain adjustments and synthesise the final value of the technical effect. Only then can we proceed to determine the economic effect.

The study of the social effectiveness of financial measures will require the use of methods of observation, interviews, questionnaires, testing, measurement, description and comparison. Only in this way we can evaluate the effectiveness and expediency of the use of financial instruments. It is well known that any changes must take some time from implementation to the planned result. At the same time, the result planned by the managers of the enterprise, region, state is not immediately realised by people. One of the clearest examples of this is the economic reform in the Republic of Poland, which was carried out under the leadership of Prime Minister Balcerowicz. Of course, we should mention the difficult state of the Polish economy, the difficulties that befell all Poles. This reform still has its critics, as some believe that it could have been done differently. Instead, the reform has its fruits, at least in a stronger national economy, the stability of the national currency. However, it came over time, albeit with a lot of work from the whole society.

The study of public policy in the field of finance requires the application of the axiomatic method, which provides for the definition of clear guidelines (axioms, axiomatic method) and longterm plans (hypotheses, hypothetical method) of parliament and government on current financial activities in the state. On the basis of experiments and modeling, formalisation of certain processes, generalisation of historical lessons of both domestic and foreign financial practice, ranking of socioeconomic problems, abstraction from populist proposals of various political and public organisations, system analysis is carried out and state and local budgets are formed to attract and use the necessary financial instruments in this period. In this case, methods of analysis and synthesis, induction and deduction, analogy should usually be used. In other words, it is impossible to develop public financial policy without the use of a range of research methods. An example is the submission of certain financial and economic projects by the government, the central bank. To convince parliamentarians and society, draw analogies with the experience of other countries, analyse their own capabilities, available resources, synthesise the projected effects of the proposed measures, take into account the effect of synergies from the integrated use of certain financial instruments. A practical example of defining public finance policy is the study and government decision to allow or prohibit the use of cryptocurrencies. Under uncertainty among government officials, financiers, bankers, and society, some countries have allowed and some have banned the use of cryptocurrencies in settlements.

The study of research funding schemes also requires a range of methods, including axiomatic, hypothetical, formalisation and abstraction, ranking and generalisation, the historical method, the method of systematic analysis, observation, description and comparison. Such a set of methods allows to study the experience of other countries, to systematise one's own domestic experience and on the basis of correctly defined priorities to provide the necessary financial resources to those scientific institutions that will provide breakthrough 
innovative development. Every country has its "limited" financial resources. Restrictions may be of different nature in different periods of development of the state, under different conditions of the national economy, under different market fluctuations in the domestic and world markets and under other circumstances. All factors will affect the definition of sources of funding, both from the state and with the participation of private investors or patrons. Undoubtedly, the priority of the state will be such projects that provide its main functions. With regard to state support for projects that are more commercial in nature, public authorities in this case are guided by the requirements of social orientation. After all, the reduction of unemployment, increasing the level of employment of certain socially vulnerable groups largely depend on the availability of jobs, on orders for certain types of products. In some cases, these are socially significant products, and in some cases they are products that can be used for social assistance abroad, but they provide an opportunity to increase the number of jobs in the country.

\section{Examples of the use of research methods in finance}

Analysis is a general method and belongs to the general scientific methods of research. However, it should be emphasised the need to deepen the understanding of this research method for a specific subject area, such as finance.

The method of analysis in financial research is the differentiation of the studied financial system or financial process into constituent elements in order to study each of them more thoroughly.

Examples include vertical and horizontal budget analysis. You can also consider analysing individual budget items or estimates. In each case, the analysis process involves differentiation, or division of the research statement or the entire financial document (plan, or report) into some components, which allows you to learn more about the details of a particular type of income (profit) or spending on certain resources.

Types of analysis are classification and periodisation.

Examples of classification include the division of the financial system into corporate finance (corporations), local and public finance, and international finance. The budgets of enterprises and organisations, local authorities and administration, and the state budget correspond to these categories. It should also be reminded of the relevant financial authorities that plan and implement these budgets. These include financial departments of enterprises and organisations, financial departments and departments of the united territorial communities (UTG), district, city and regional public authorities, ministries and departments, the Ministry of Finance. As for international finance, they are represented by international financial organisations: the International Monetary Fund (IMF), the European Bank for Reconstruction and Development (EBRD), as well as similar banks on other continents, the World Bank and others.

Examples of periodisation are the time division of financial activities depending on the emergence of different types of means of payment, the emergence of systematic accounting of financial transactions, the emergence of budgets and changes in revenues and expenditures, changes in the tax system, changes in financial management, the emergence of financial companies national and international legislation in the field of finance, etc.

Synthesis belongs to general scientific research methods. However, understanding this method of research requires clarification for "finance" as a subject area of research. The method of synthesis in financial research is an assumption about the combination of components or elements of the studied financial units or financial instruments in order to study them as a whole.

Take by analogy accounting, where the final, summary or synthetic result of the balance sheet is an indicator of the balance sheet currency. In the financial plans and reports it is also possible to note certain generalising results on separate sections of estimates and budgets which are final, integrating, synthetic indicators.

Synthesis, as a method of research in finance, allows you to make the right management decisions to create, organise and reorganise individual production, government agencies, public and political organisations, local communities and so on.

Methods of analysis and synthesis are interrelated, they are used in research in combination. The analysis allows us to answer 


\section{Alieksieiev, A. Mazur, A. Moroz}

questions about the in-depth individual characteristics of the financial functioning of a business entity or territorial community, administrative territory. And the synthesis allows us to see the prospect of unification, joint production, economic activity, ensuring innovative development according to modern requirements.

Market principles of management provide daily examples of mergers or acquisitions of some corporations to others. Such decisions are made based on the results of the analysis of current activities and consideration of development prospects on the basis of synthetic indicators that reflect the total income, expenses, results of activities. Examples of such processes are mergers or amalgamations of banks in Switzerland, Ukraine, and the consolidation of automobile companies in Europe, USA, and South Korea. At the same time, such tendencies have an interstate, global character.

As for the administrative-territorial aspect, examples are Great Britain in the 1970s, the Republic of Poland in the early 21st century, when the consolidation of counties in the UK and communes in Poland led to the strengthening of local budgets. Such a reform was envisaged in Ukraine at the end of the 20th and the beginning of the 21 st century, but has not yet been fully implemented. The decision of the Verkhovna Rada of Ukraine on the consolidation of districts in the regions was adopted in 2020. Instead, there is a lot of work ahead to streamline the authorities and management in the new districts, analysis and determination of the financial capacity of these new territorial entities, which are formed of several UTCs. It is known that not all united territorial communities are financially viable. As a result, districts may be unable to implement the necessary social projects and programs at the expense of their own financial resources.

Induction belongs to general scientific research methods. Regarding this method, it is better known from the philosophical and technical literature. Instead of the financial subject area of research, it is difficult to find in-depth research on this method. However, as in other activities, the method of induction may sometimes be beyond conscious perception, but is used by practitioners and scientists. In particular, this applies to cases: (a) the individual experience of the financial work of a corporation or financial institutions, (b) the use and distribution of a financial instrument (eg certain derivative etc.) in different structural entities. Therefore, there is a need to interpret this research method for a specific financial area.

The method of induction in financial research is a generalisation of conclusions from observations of a set of disparate facts, trends in the use of financial instruments, experience of financial work, which allows formulating general provisions, principles, laws.

Examples of using the induction method include the already mentioned derivatives, which became widespread after certain operations, which in some cases allowed unlocking the problems of temporary defaults. Also, the results of using the method of induction include the strengthening of local budgets through the spread of international practice of consolidation of territorial communities. Of course, combining two or more budgets does not generate more revenue than simply compiling separate budgets. Instead, the larger amount of funds available to the authorities of the enlarged territorial community allows for the consistent implementation of larger projects in all former small communities and the solution of socioeconomic problems when it would be impossible to do so separately.

Deduction belongs to general scientific research methods. However, here we should also say about a certain specificity of the view on such a method, which is deduction. After all, social, natural and technical sciences derive certain laws of development of society, natural phenomena, laws of functioning of technical means in certain technological processes and then use the obtained general rules (laws, principles, etc.) for certain socio-political conditions (methods of governing states, development and civilisations, etc.), to find new means and methods of production, to organise and manage enterprises and so on. If in the field of finance it is possible to formulate certain generaliied approaches to financial policy, financial cooperation at different levels (from international, interstate to intercorporate), then such approaches can be used for a narrow range of financial relations - in a country that has not yet implemented certain financial innovations, or a 
corporation which has not yet used some financial tools, financial technology.

The method of deduction in financial research is the conclusion of the application of certain financial instruments and technologies for a particular case, based on the general provisions, principles and laws.

An example of the use of the deduction method is the introduction of blockchain technology in the financial sector. After all, the technology itself originated in the field of information technology (IT) and is generally intended for the use of computer technology. Instead, like many other advances in science and technology, it has become more widespread and, among other things, has proved to be very effective for financial and credit operations.

Observations and descriptions are empirical research methods that are not given much attention in modern conditions. Although for the science of astronomy, observation is probably the most important, key method. After all, only close observation, combined with comparison, can answer questions about new objects in galaxies and about galaxies themselves. Observation is also an important method of research in medicine and biology. In current mode, observation is an important method of border protection, law enforcement and preservation of property against fire and theft. At the present stage for observation there are used high-power tools: telescopes, microscopes, video surveillance. If in astronomy and medicine it is possible to consider observation as a purely scientific method, then the use of observation for protective purposes is a method of current research.

As for the description, this method is used in all studies. Instead, it is hardly possible to see the name of this method in dissertations in the list of used research methods. However, the description is an extremely important method, which will be mentioned by legal investigators. It is a series of descriptions from interrogations that make it possible to reveal false testimony. With regard to financial and economic activities, we should mention accounting documents, financial statements, which are specific descriptions of production and economic activities and from which we can draw a lot of different conclusions to identify financial irregularities, to identify ways to improve not only purely financial work but also organisation of production and economic activities.

Another empirical method is comparison, which also belongs to general scientific research methods. Comparison is confronting features inherent in two or more objects, designed to establish differences between them or to find common ground in them. Comparison is a common method. Even when people have not studied the classification of research methods, when they do not even think that they are conducting any research, they use comparisons. In different cases, the objects of comparison are different phenomena, processes, countries, territories, enterprises and organisations, and finally the people themselves, who are compared in terms of anthropometric, psycho-emotional, professional and other characteristics. All this is more or less familiar to everyone. On the other hand, with regard to special subject areas, the method of comparison in this case is not always sufficiently disclosed and described. This also applies to the method of comparison in the subject area of "finance", and therefore requires specification.

The method of comparison in financial research is the comparison of features inherent in two or more financial categories, such as financial instruments, parts of the financial system, etc., and is designed to identify differences between them or find common ground. This allows you to use them in a certain set or sequence (for example, financial instruments) or integrate (for example, funds of financial resources for various purposes) to joint projects.

Examples of using the comparison method are international comparisons of state budgets and their statements, state and non-state pension funds, taxation systems, insurance, the structure of the banking system and national conditions of financial market regulators, and so on.

The experiment is an empirical method and belongs to the general scientific methods of research. Experiments have not become widespread in economics and finance. Instead, there are historical examples of experiments in economics and finance. Experiments in the financial and economic sphere take a long time, as it is impossible to determine the financial and economic 


\section{Alieksieiev, A. Mazur, A. Moroz}

consequences of such innovations in one day, month, year, and sometimes decades. That is why we are talking about historical experience, domestic and foreign.

The method of experiment in the financial sphere is to conduct financial and economic measures to identify the reactions of participants in financial and economic relations to the proposed financial instruments and the changes they cause in different parts of the financial system and the economy of the state or region.

It is no coincidence that we are talking about financial and economic measures when using the method of experiment in financial research. After all, financial changes or the introduction of financial innovations are accompanied by largescale economic reforms.

In the early 1990s, a new income tax scale was introduced in Ukraine (now it is a personal income tax). A characteristic feature of that progressive tax scale was the establishment of a maximum rate of $90 \%$ of income (a shedular approach was used, according to which each shedula, ie each subsequent amount of income, was taxed at a certain higher amount of tax). The practice of using such a progressive tax scale did not work, as employers and employees did not show income above the amount that was taxed at $30 \%$. In the socio-economic aspect, such an "experiment" can be considered harmful because it pushed for the shadow payment of wages.

A well-known example of the use of derivatives, which led to the global financial crisis of defaults at the end of the 20th century, can also be considered a rather long financial experiment. The crisis was triggered by failed speculations in South Asian stock markets, and the result - the mass bankruptcy of companies around the world.

Successful economic reforms in Poland in the 1990s were accompanied by serious financial measures, which at first significantly limited both business and citizens. Instead, later the whole set of financial and economic measures led to the development of the Polish economy.

The method of modeling in the financial sphere is an attempt to reflect the real conditions of financial instruments using economic and mathematical methods to assess the likely reactions of participants in financial and economic relations to the proposed financial instruments and the changes they cause in different parts of the financial system.

At the present stage of development of science in the field of information technology and programming, the modeling method is used very widely. In particular, examples of modeling in finance include the development of variable budget forecasts, financial plans, development programs for financial and credit institutions, and so on. That is, without modeling none of the financial issues, in countries with developed economies, digitalisation of financial and credit processes, are solved.

\section{General and special characteristics of research in the field of finance}

It is important (for those who have to conduct financial research) to understand and be aware of certain well-known and accepted aspects of research practice, as well as to develop their own special approach to research.

The question of classification of sciences is important for understanding the scientific approaches, as each of scientific directions has the specific conditions of functioning and accordingly - a methodology of carrying out researches. For financiers, knowledge of the specifics of certain scientific fields is important, in terms of both - the peculiarities of the financial support of such branches of science, and the possible use of some approaches to these types of science to conduct own research.

Mastering the scientific approach to the study of various socio-economic and financial phenomena is a necessary basis for the competent and reasonable use of research methods. Knowledge of the system of scientific research is an important aspect of achieving effective results not only in science but also in the process of current research, which aims to improve the activities of any enterprise, organisation, institution. This consistency provides, in particular, the need for consistent: (1) awareness, establishment and pursuit of the goals of scientific (prospective) or current research; (2) understanding the nature and characteristics of the planned research process; (3) understanding of the scientific, theoretical basis for the study; (4) awareness of the need to identify sources and amounts of funding to provide research; (5) awareness of research priorities. 


\section{Methodology of prospective and current research in finance}

It is important for financiers to know about the differences between different perceptions of reality, and accordingly about the way it is studied by representatives of different professional groups. Such differences in the perception of phenomena are often the cause not only of substantive differences, but also the perception of the need for financial support of a process. In particular, it is important to understand the differences between aesthetic and scientific perception. Also, along with the development of science and research methods, the content and certain features of research are changing. The need to solve urgent promising problems in the financial sector creates a deepening of research on financial relations, expanding the range of financial instruments. Accordingly, new financial institutions appear, financial legislation changes. That is, there is not only an increase in the "amount" of experience and positive knowledge about the development of the financial system, but also a change in the entire structure of the financial and credit relations and the research methods used in it.

Scientific (theoretical) research base should be considered as a system consisting of: theory; research methodologies and techniques; practices of implementation of the obtained results. The data obtained from the results of scientific (prospective) research, if we talk about the financial sphere, are necessary for further use in financial or credit institutions. On this basis, current research is being conducted to improve indicators, use new financial instruments, implement innovative financial procedures based on the use of IT technologies, new ways of working with clients, achieve positive development, including attracting new investors.

In the aspect of current researches the reporting data allow to study a concrete situation and to define directions of improvement of financial institutions' activity. In the context of both current and future (scientific) research, factual data allow scientists to predict trends in financial institutions, the financial system, and the prospects for the use of certain financial instruments, interaction with customers, financial intermediaries and competitors in financial markets.

Financial aspects in the system of scientific (prospective) and current research should be considered: firstly, in terms of stakeholders as: national interests, the interests of representatives of certain industries and the interests of business entities; secondly, in terms of direct participation in the formation of appropriate funds for research funding; thirdly, in terms of recipients of funds for scientific or current research; fourthly, in terms of recipients of the share of profits (losses) from the implementation of scientific or practical projects, ie from the successful (unsuccessful) implementation of the results of scientific and / or current research.

Financiers will always be faced with the need and adequacy of funding for certain types of research. If the need for current research and their funding is dictated by the immediate needs of the enterprise, organisation or institution, and therefore may not cause serious questions, then scientific (prospective) research always raises questions about their feasibility, and even more so the financial costs. That is why there is a need to clarify the directions of scientific and technological development, their impact on the economy and finance. And not only in terms of costs, but also in terms of prospects for profit due to the introduction of new technologies, new types of equipment, new management decision-making procedures, the use of new software products.

Financiers work in various spheres of economic activity, where they are responsible for full and timely financing of relevant works, and in scientific institutions - for financing research and scientific and technical development. That is why the financier should have an idea of the specifics of prospective and current research in various fields, including the natural and social sciences.

Natural sciences study the phenomena and laws of development of nature, the properties of the physical world. The social sciences deal with human behavior and social institutions. The specificity of research in these fields of science is that the results obtained mostly can not be estimated in in value terms. It is possible to measure the costs of such research, but it is impossible to measure any economic effect.

To successfully conduct a prospective or current research, it must be properly planned, organized and performed in a certain sequence. These plans and the steps depend on the type, subject and research purposes. So, if it is held for the technical subject, then you must first develop a basic document - a feasibility study and then carry 


\section{Alieksieiev, A. Mazur, A. Moroz}

out theoretical and experimental research, make scientific and technical report and implement the work in production.

If the research is conducted on a financial topic, then first an order or decree is issued, which determines the purpose of the research, the necessary resources (human and material) and the deadline. After that, the results of the study are reported to management, and managers decide to implement the results of the study and issue an order indicating in what form these results should be implemented.

Researching financial efficiency is a rather complex process. Firstly, the category of "efficiency" is perceived in at least two aspects: as the ratio of the cost of the economic result to the cost of obtaining this result; and as a generic name for all aspects of effects evaluating. Such effects include: economic effect as an absolute indicator (the value of the change in a certain parameter of production activity, ie change in cost, profit, etc.); economic efficiency as a relative indicator; social efficiency; environmental efficiency. The last two types of efficiency are often not valued, but in some cases can be measured in both absolute and relative units, which characterise changes in certain parameters of the social and / or environmental environment. Based on this, it is necessary to draw a conclusion about the different indicators of measuring efficiency, which in turn leads to the use of different methods for such measurement. Typically, such methods are used in the complex necessary for the most accurate determination of the result.

It is also necessary to single out the definition of efficiency both as a result of the direct implementation of financial measures and the determination of the possible effectiveness of financial research. The result will usually be determined in the field of material production or in financial markets. Both in the first and in the second case it is necessary to use well-known methods of estimation of effects, efficiency, payback periods, turnover terms, etc.

\section{Conclusions}

The research of publications on methodological topics, both general theoretical and special, including financial, allowed to identify certain problems in covering issues of methodology. In particular, it was found that methodological developments are aimed primarily at scientific research. Instead, research to improve the condition of enterprises, organisations and institutions, ie those that do not necessarily require scientific novelty, are not covered by published research. Of course, it can be assumed, as it happens in real life, that practitioners use scientific advances in methodology in their work projects. However, when it comes to the need to determine the content of academic courses, then in educational and professional and especially in educational and scientific programs of the educational level of Master the course of "research" is included. The same is called the course for the Doctoral educational level $(\mathrm{PhD})$. Teachers and students of the appropriate educational level understand that there must be some difference in the content of teaching, which must be aimed at different results. This is achieved through a clearer definition of competencies at each level of education.

However, to date, this is not clearly formulated in textbooks and manuals. To solve this problem, we propose to consider research with their division into prospective, ie scientific (fundamental and applied), and current, which are aimed at developing recommendations for improving certain issues in the activities of enterprises, organisations and institutions.

In addition, the analysis of dissertations submitted for a doctorate degree shows that to a large extent researchers do not use all methods and indicate only a limited number of them to study a specific problem in a particular field of science and practice, including financial sphere. We have developed and proposed a matrix that allows a comprehensive approach to determining the range of methods that are needed to study the problem on a particular topic. From the matrix developed and presented it follows that for realiiation of some research it is necessary to use some methods which can make a certain complex, however can be used also separately. The argumentation of the use of certain sets of methods for several examples with an illustration of the practical experience of financial activities is given. There is also a justification for the need for researchers of the financial system to master well-known approaches to conducting not only promising (scientific) 


\section{Methodology of prospective and current research in finance}

research, but also current research to improve current work.

Our results can be useful in future research on various problems of the financial system. In particular, our proposed matrix of forming the complexes of research methods can serve as a basis for further methodological research on the synthesis of research methods for new problems and challenges in the financial system, as well as in other areas.

\section{References}

1. Garafonova, O. (2014). Upravlinnia zminamy: teoriia, metodolohiia ta praktyka [Change management: theory, methodology and practice]. Kyiv National University of Technology and Design, [in Ukrainian].

2. Kerry E Howell (2012). An Introduction to the Philosophy of Methodology. University of Plymouth, UK, SAGE Publications Ltd.

3. Kothari, C.R. (2004). Methodology Methods and Techniques. New Age International (P) Ltd.

4. Malcolm Williams (2016). Key Concepts in the Philosophy of Social Research. University of Cardiff, UK, SAGE Publications Ltd.

5. Mints, O. (2017). Metodolohiia modeliuvannia innovatsiinykh intelektualnykh system pryiniattia rishen $v$ ekonomitsi [Methodology for modeling innovative intelligent decision-making systems in economics]. Mariupol: Priazovskyi State Technical University. [in Ukrainian].

6. Pernecky, Tomas (2016). Epistomology and Metaphysics for Qualitative Research. Auckland University of Technology, New Zeland, SAGE Publications Ltd.

7. Tuck, Eve \& McKenzie, Marcia (2014). Place in Research: Theory, Methodology, and Methods. Taylor \& Francis.

8. Cekhmistrova, H. (2003). Osnovy naukovoho doslidzhennia [Fundamentals of scientific research]. Kyiv, Slovo Publishing House. [in Ukrainian].

9. Danylian, O. \& Dzioban O. (2017). Orhanizatsiia ta metodolohiia naukovykh doslidzhen [Organisation and methodology of scientific research]. Kharkiv, Pravo Publishing House. [in Ukrainian].

10. Jonker, Jan \& Pennink, Bartjan (2010) The Essence of Research Methodology: A Concise Guide for Master and PhD Students in Management Science. Springer Heidelberg Dordrecht London New York

11. Konverskyi, A. \& others (2010). Osnovy metodolohiii ta orhanizatsiii naukovykh doslidzhen [Fundamentals of methodology and organization of scientific research]. Kuiv, Center for Educational Literature. [in Ukrainian].

12. Kraus, N. (2012). Metodolohiia ta orhanizatsiia naukovykh doslidzhen [Methodology and organization of scientific research]. Poltava, Oriiana Publishing House. [in Ukrainian].

13. Ludchenko, Y. (2013). Otsinka economichnoii efectyvnosti investytsii z urakhuvanniam ryzykiv [assessment of economic efficiency of investments taking into account risks]. Kyiv, Lohos. [in Ukrainian].

14. Kyrylenko, O. \& others (2012). Metodyka ta orhanizatsiia naukovykh doslidzhen [Methods and organization of scientific research]. Kyiv, Economic thought. [in Ukrainian].

15. Martsyn, V., Mitsenko, N. \& Danylenko, O. (2002). Osnovy naukovukh doslidzhen [Fundamentals of scientific research]. Lviv, Romus-Polihraph. [in Ukrainian].

16. Mishchenko, I., Chornyi, G. \& Fishchuk, N. (2017). Metodolohiia doslidzhen $v$ konteksti dysertatsiinykh I dyplomnykh robit $z$ ekonomiky [Research methodology in the context of dissertations and dissertations in economics]. Economics of AIC, No. 1, 87-91. [in Ukrainian].

17. Orlov, V., Novytska, S. \& Yatskevych, I. (2011). Osnovy metodolohii doslidzhen v komunikatsiinii ekonomitsi [Fundamentals of research methodology in communication economics]. Odessa, VMV. [in Ukrainian]

18. Romanchykov, V. (2007). Osnovy naukovykh doslidzhen [Fundamentals of scientific research]. Kyiv, Publishing House "Center for Educational Literature" [in Ukrainian].

19. Vazhynskii, S. \& Shcherbak, T. (2016). Metodyka ta orhanizatsiia naukovykh doslidzhen [Methods and organization of scientific research]. Sumy, Sumy State Pedagogical University named A. S. Makarenko. [in Ukrainian].

20. Zatserkovnyi, V., Tishaiev, I. \& Demydov, V. (2017). Metodolohiia naukovykh doslidzhen [Research methodology]. Kyiv, Taras Shevchenko Kyiv State University. Nizhyn, Nizhyn Mykola Gogol State University [in Ukrainian].

21. Martynov, S. \& Orlov, V. (2013). Informatsiini tekhnolohiii v naukovykh rozrobkakh [Information technologies in scientific developments]. Rivne, National University of Water Management and Environmental Management. [in Ukrainian].

22. Sharavara, T. (2017). Informatsiinyi poshuk $i$ robota $z$ bibliotechnymy resursamy [Information search and work with library resources]. Poltava, Poltava State Agrarian Academy. [in Ukrainian]. 


\section{Alieksieiev, A. Mazur, A. Moroz}

23. Azarenkova, G.M. (2007). Financial flows of the economic agents: methodology and organization of management. - Manuscript. Dissertation for a Doctorate Degree in Economic Sciences by specialty - Money, finance and credit. - Ukrainian Academy of Banking of National Bank of Ukraine, Sumy. [in Ukrainian].

24. Kharlamova, O. (2016). Transparent Financial Statements Execution Methodology and Architectonics. Manuscript, Thesis work to obtain the Doctor of Economics scientific degree in specialty 08.00.09. - Accounting, Analysis and Audit. [in Ukrainian].

25. Kornieiev, M. (2015). Methodological bases of estimation and regulation of imbalances of movement of financial resources in economy of Ukraine. Dissertation for a Doctorate Degree in Economic Sciences by specialty 08.00.08 - money, finance and credit, Sumy. [in Ukrainian].

26. Kornieiev, V. (2004). Upravlinnia kredytnymy ta investytsiinymy potokamy kapitalu [Management of Credit and Investment Capital Flows]. Dissertation for a Doctorate Degree in Economic Sciences by specialty 08.04.01 - Finances, Money Turnover and Credit, Kyiv. [in Ukrainian].

27. Tarangul, L.L. (2003). Tax Policy and Economic Development of Regions: Theory, Methodology, Practice. Dissertation for a Doctorate Degree in Economic Sciences by specialty 08.04.01 Finances, Money Turnover and Credit, Kyiv.

28. Bob Ryan, Robert W. Scapens \& Michael Theobold. (2002). Research Method and Methodology in Finance and Accounting Second Edition. TJ Digital, Padstow UK.

29. Boronos, V. (2011) Metodolohichni zasady upravlinnia finansovym potentsialom terytoriii [Methodological principles of managing the financial potential of the territory]. Sumy, Sumy national University. [in Ukrainian].

30. Dyba, M. \& Maiorova, T. (2013). Teoretykometodolohichni zasady doslidzhennia investytsiinoho protsesu u finansovii nautsi [Theoretical and methodological principles of investment process research in financial science]. Finance of Ukraine, 2, 103-109. [in Ukrainian].

31. Ivanov, Yu. \& Udovenko, A. (2015). Metodychnyi pidhid do otsinky diievosti zahodiv $v$ sferi derehuliuvannia [Methodical approach to assessing the effectiveness of measures in the field of deregulation of the Ukrainian economy]. Scientific Bulletin of Uzhhorod University, “Economics” series, 2 (46), 59-65. [in Ukrainian].

32. Kneisler, O. V. (2015). Metodolohiia klasyfikatsii finansovykh potokiv strakhovykh kompanii. [Methodology of classification of insurance companies financial flows] Ekonomichnyi analiz, 20, 157-163 [in Ukrainian].

33. Laktionova, O. (2016). Hnuchkist finansovoii systemy: metodolohiia, otsinka ta vektory zabazpechennia [Flexibility of the financial system: methodology, evaluation and vectors]. Vinnytsia. [in Ukrainian].

34. Lomachynska, I. (2009). Teoretyko-metodolohichni osnovy mekhanizmu zbalansuvavvia finansiv pidpryiemstv [Theoretical and methodological bases of the mechanism of finances of enterprises balancing. Odessa National I.I. Mechnikov University, 71-83. [in Ukrainian].

35. Martiusheva, L. (2011). Metodolohichni osnovy orhanizatsiii finansovoii bezpeky pidpryiemstva [Arrangement of methodological principles of enterprise financial security]. Financial Space, 1 (1), 85-90. [in Ukrainian].

36. Paientko, T. (2013). Instytutsionalizatsiia fiskalnoho rehuliuvannia finansovyh potokiv [Institutionalization of fiscal regulation of financial flows]. Monograph, Kyiv, "DKS center". [in Ukrainian].

37. Tulai, O. (2019). Metodolohichni aspekty dostidzhennia derzhavnyh finansiv [Methodological aspects of state finance studies]. Economic Forum, 1, 158-166. [in Ukrainian].

38. Reinhard H. Schmidt. (1982). Methodology and finance. Theory and Decision, 14(4), GoetheUniversität Frankfurt am Main.

39. Sean, Peek. (2020). Small Business Financing Options That Bypass Traditional Banks. Business Neus Daily.

40. Volokhova, I. (2014) Metodolohiia vyznachennia stupenia finansovoii detsentralizatsiii po vudatkah [Methodology of determination of degree of financial decentralization on charges]. European Journal of Economics and Management, 1, 84-90. [in Ukrainian]

41. Williams, C. (2007). Research Methods. Journal of Business \& Economics Research (JBER), No. 5(3). 